\title{
Content of ingredients of chemical composition of fruits of dogwood (Cornus Mas. L.) depending on the kind and weather environment
}

\author{
Ye. Postolenko, PhD, \\ L.P. Symyrenko Institute of pomology, NAAS of Ukraine,
}

The purpose. To study influence of features of a kind and weather environment upon formation of the content of essential ingredients of chemical composition in fruits of dogwood grown in Right-bank Foreststeppe of Ukraine. Methods. Laboratory, chemical, comparative-calculation. Results. In conditions of Right-bank Forest-steppe depending on the kind and weather environment of growing fruits of dogwood accumulate: dry matters - 18,5-26,8\%; dry soluble substance $-15,6-23,9$; sugars $-5,9-$ 10,5; acids - 2,38 - 3,10\%; ascorbic acids - 70,2 - 93,6 mg/100 g. Conclusions. Strong converse connections between the content of dry solvends in fruits and rainfall of vegetation period are determined: with increase of rainfall the content of dry solvends and total sugars in fruits is decreased. Essential influence of weather environment in winter-spring season, in particular rainfalls, on the content of dry solvends, sugars and titrable acids in fruits of dogwood is fixed.

Key words: dogwood, kind, weather environment, chemical composition.

In the plant world in our country there are many useful plant species that little or no use. It belongs to them dogwood - a very ancient fruit plant, is valuable as food, medicine, of soil, decorative, used in the Neolithic. Cornel ordinary (Cornus mas L) - european species, only one table with many other types of dogwood, which are cultivated in our country [1-3].

In recent years, as dogwood culture of medical-prophylactic leading value acquired in foreign countries, including: China, Slovakia, Turkey [4-6].

The chemical composition of the fruits of dogwood varies from year to year, the content of certain substances is also changing - it all depends on the intensity of light, heat and moisture availability, varying in different weather and climatic conditions. We know that sugar is accumulated by intense sunlight, acid at lower temperatures $[7,8]$.

Natural conditions of the area growing significantly affect the content in the fruits of dogwood minerals and other compounds. Dry, hot weather negatively affects the accumulation of vitamin $C$ in the fruit. In years with high rainfall content of ascorbic acid in fruit increased [9, 10].

The purpose of research - the study of general patterns of the contents of the main components of the chemical composition of the fruit dogwood grown in Right-bank Forest Steppe of Ukraine.

Materials and methods of research. The study was conducted during 2011-2013. At the L.P Symyrenka Instituteof pomology, NAAS of Ukraine. We used the fruits of dogwood early ripening period Elena, Mykhailivsky; medium term ripening - Eugeniya, Lukianivky, Vydubetsky. To control were taken best zoned varieties Right-Bank Forest-Steppe zone of Ukraine Elena - for early varieties ripening period; Eugeniya - for medium term ripening. The scheme of planting - 3,5 ×3,5 m.

Chemical analysis of the dogwood fresh fruit carried out in accordance with the "Methodology for assessing the quality of fruits and berries" [11].

Indicators weather conditions measured on meteorological L.P Simirenko Institute of pomology.

Software implementation of statistical analysis of experimental data performed by techniques $B$. Dospyehov [12] office applications Misrosoft Excel 2003, Statistica 7, Agrostat.

Research results. The content of chemical components dogwood fruits are shown in Table 1. 
1.Vmist components of the chemical composition of the fruit varieties dogwood, 2011-2013.

\begin{tabular}{|c|c|c|c|c|c|c|}
\hline \multirow[b]{2}{*}{ Varieties } & \multirow[b]{2}{*}{$\begin{array}{l}\text { Year } \\
\text { harvest }\end{array}$} & \multicolumn{5}{|l|}{ Contents } \\
\hline & & solids, $\%$ & $\begin{array}{l}\text { solution-dry } \\
\text { substances, } \%\end{array}$ & $\begin{array}{l}\text { total } \\
\text { sugars } \%\end{array}$ & acids, \% & $\begin{array}{l}\text { askor- } \\
\text { binovoy acid } \\
\text { mg / 100r }\end{array}$ \\
\hline \multicolumn{7}{|c|}{ Varieties of early ripening period } \\
\hline \multirow{3}{*}{ Elena (control) } & 2011 & 20,2 & 17,10 & 6,30 & 2,40 & 81,4 \\
\hline & 2012 & 25,0 & 20,98 & 7,60 & 2,44 & 80,6 \\
\hline & 2013 & 26,8 & 23,90 & 10,50 & 3,03 & 88,4 \\
\hline \multicolumn{2}{|l|}{ Average } & 24,0 & 20,66 & 8,13 & 2,62 & 83,5 \\
\hline \multirow{3}{*}{ Mykhailivsky } & 2011 & 20,1 & 17,60 & 6,90 & 3,04 & 85,8 \\
\hline & 2012 & 23,8 & 19,38 & 6,73 & 3,07 & 83,2 \\
\hline & 2013 & 26,6 & 23,70 & 9,30 & 3,10 & 91,0 \\
\hline \multicolumn{2}{|l|}{ Average } & 23,5 & 20,23 & 7,64 & 3,07 & 86,7 \\
\hline \multicolumn{2}{|l|}{$\mathrm{SSD}_{05}$} & 0,40 & 0,30 & 0,20 & 0,10 & 0,70 \\
\hline \multicolumn{7}{|c|}{ Varieties of medium term ripening period } \\
\hline \multirow{3}{*}{ Eugeniya (control) } & 2011 & 19,1 & 15,90 & 6,56 & 2,95 & 80,6 \\
\hline & 2012 & 23,6 & 20,58 & 8,47 & 2,54 & 78,0 \\
\hline & 2013 & 25,7 & 23,0 & 10,50 & 2,73 & 85,8 \\
\hline \multicolumn{2}{|l|}{ Average } & 22,8 & $\mid 19,83$ & 8,51 & 2,74 & 81,5 \\
\hline \multirow{3}{*}{ Lukyanovsky } & 2011 & 18,7 & 15,60 & 5,90 & 2,41 & 70,2 \\
\hline & 2012 & 22,7 & 21,18 & 9,83 & 2,38 & 74,1 \\
\hline & 2013 & 25,5 & 22,60 & 8,13 & 3,04 & 80,6 \\
\hline \multicolumn{2}{|l|}{ Average } & 22,3 & 19,79 & 7,95 & 2,61 & 75,0 \\
\hline \multirow{3}{*}{ Vidubecky } & 2011 & 18,5 & 16,10 & 6,40 & 2,56 & 88,4 \\
\hline & 2012 & 24,8 & 20,78 & 7,93 & 2,47 & 84,5 \\
\hline & 2013 & 26,4 & 23,50 & 8,63 & 3,08 & 93,6 \\
\hline \multicolumn{2}{|l|}{ Average } & 23,2 & 20,13 & 7,65 & 2,70 & 88,8 \\
\hline \multicolumn{2}{|l|}{$S S D_{05}$} & 0,30 & 0,30 & 0,20 & 0,10 & 0,90 \\
\hline
\end{tabular}

Our studies provide an opportunity to argue that solids content in fruits of early varieties Mykhailivsky, Elena (control) in 2011 and 2013 did not differ significantly. In 2012, the dry matter content in the fruits of dogwood Elena (control) is significantly greater than the fruit varieties Mykhailivsky difference - $1.2 \%$ more SSD $05=0.40$. But within the same class for years observed significant differences on the content of solids, in particular, in 2013 the fruit variety Elena content was the highest, which was $26.8 \%$ in 2012 less than the fruit growing in 2013 at $1,8 \%$ and, respectively, in $2011-$ by $6.6 \%$. A similar trend was observed for fruit varieties Mykhailivsky. 
In Medium dogwood fruit varieties and most solids accumulation took place in 2013. The advantage of the fruits of the harvest 2012 and 2011 this indicator amounted to sort Eugeniya, respectively, 1.1 and 1.3 times; the class Lukyanovsky and Vidubecky - at 1.1 and 1.4 times. Differences dry matter content for Medium fruit varieties dogwood within 2011 were $0.4-0.6 \%$ in $2012-0,9-1,2 \%$, showing significant this difference between varieties. In 2013, Eugene and fruit varieties Lukyanovsky contain almost the same amount of solids, and the fruit variety Vidubecky were significantly more (0.7-0.9\%).

The content in the fruits of dogwood solids content of dry exceed soluble substances determined by refractometer at $1,5-4,0 \%$.

The content of dry soluble substances in fruits dogwood grown in terms of Right-Bank Forest-Steppe Ukraine, varied depending on the variety and conditions of the year. In 2011 the lowest average and the sum of active temperatures during the growing season and the largest amount of rainfall in the fruits of all varieties accumulated the least amount as dry soluble and total solids. In 2012 and 2013 during the growing season rainfall dogwood differed by only $1.9 \mathrm{~mm}$, ie providing moisture plant was about the same. However, the fruit harvest in 2013 of total and soluble solids was significantly higher compared to fruit harvest 2012. In our view, this can be explained by the fact that in 2012 had the highest average temperature $\left(17,7^{\circ} \mathrm{C}\right)$ and the amount of active temperatures $-3655,2^{\circ} \mathrm{C}$ and the mediocre moisture, growing conditions turned out to be dry.

So, for the formation of crop dogwood fruits are high in essential nutrients is the optimal ratio between the amount of active temperature and precipitation during the growing season, especially in terms of Right-Bank forest-Steppe Ukraine - is the amount of active substances is $3228,2{ }^{\circ} \mathrm{C}$ and precipitation: 356, $1 \mathrm{~mm}(2013)$.

Sugars in fruits dogwood accumulated by laws analogous to the accumulation of soluble dry substances, and during the studies varied depending on conditions, the cultivation.

The analysis of the chemical composition of the dogwood makes it possible to assert that the acid content of fruit early varieties Mykhailivsky, Elena (control) differed significantly. If you compare the contents of acids in the Medium varieties Eugeniya, (control), and Lukyanovsky, Vidubecky, we also observed a significant difference between them, within one year of the study (Table. 1).

Among the varieties of fruits Medium high content of ascorbic acid fruit varieties distinguished Vidubecky $(88.8 \mathrm{mg} / 100 \mathrm{~g}$ ), which exceeded the averages for fruit varieties Eugeniya (control) and Lukyanovsky, respectively, $7.3 \mathrm{mg} / 100 \mathrm{~g}$ and $138 \mathrm{mg} / 100 \mathrm{~g}$

Analyzing the impact of weather conditions, the growing season for accumulation of ascorbic acid in fruits of dogwood should be noted that the highest amount of active and average temperatures in the growing season (2012) in the fruit variety Mykhailivsky, Elena, Eugeniya, (control), and Vidubecky accumulated the least amount of ascorbic acid, except by Lukyanovsky fruit varieties.

Detailed analysis of the chemical composition of the fruits of dogwood during the study demonstrates the significant impact of weather conditions, the cultivation of their changes: in 2013, the contents of these components of the chemical composition of the fruits of all investigated varieties of dogwood was significantly higher compared to 2011 and 2012 years.

Correlation analysis between agroclimatic indicators of the growing season and the contents of chemical components showed that the increase in average temperature and the amount of active temperatures increases the content of soluble dry matter in fruits dogwood.

This statement is confirmed by correlation, respectively, $r=0,79 \pm 0,01$ and $r=0,56 \pm 0,05$. Revealed strong inverse relationships between the content of soluble dry matter in the fruit and the amount of rainfall the vegetation period, with an increase in rainfall in the fruit decreases the content of dry soluble substances $(r=-0,94 \pm 0,00)$ and total sugars $(r=-0,94 \pm 0,00)$, respectively, with the growth also happened reduction of soluble dry matter $(r=-0,91 \pm 000)$ and sugars $(r=-0,76 \pm 0,01)$.

According to the correlation analysis between the growing season weather conditions and maintenance of a volumetric acid and ascorbic acid in fruit found weak correlations.

According A. Leopold [13] for the formation of a crop plant fruit crops are the main source of substances photosynthetic leaves and other tissue growth which depends on weather conditions, primarily on the supply of water that accumulates in the winter-spring period. 
According to the research found, with increasing rainfall winter-spring period there was an increase of dry soluble substances, sugars in the fruit, which was confirmed by close correlations, respectively, $r=$ $0,94 \pm 0,00$ and $r=0,94 \pm 000$. Found correlation between moderate strength acid content in the fruit and the amount of precipitation winter-spring period, with an increase in rainfall in the fruit growing content titrated acids that confirmed a correlation coefficient that is $r=0,52 \pm 0,05$.

Consequently, the supply of moisture the winter-spring period of a year is the key to the accumulation of the main components of the chemical composition of the fruits of dogwood that in our studies: in 2011, the contents of chemical components was: dry soluble substances - $15,6-17,6 \%$, sugar $-5,9-6,9 \%$ and acids $-2,40-3,07 \%$ in the amount of precipitation for the winter-spring period $118.1 \mathrm{~mm}$, and in 2013 the content of soluble dry matter, sugars and acids varieties made: $22,6-23,9 \% 8,13-10,5 \%$ and $2,73-3,10 \%$, which is significantly higher compared to 2011 , this can be explained by the high amount of rainfall winterspring period, which was $345.7 \mathrm{~mm}$.

Our study consistent with the statement V. Polyevoy [14] that the shortage of moisture the winterspring period the total number of synthesized substances, proteins, lipids, sugars and other substances in plants significantly reduced.

\section{Conclusions}

Depending on the type of vegetation and weather conditions dogwood fruits accumulate $18,5-26,8 \%$ solids $15,6-23,9 \%$ - dry soluble substances $5,9-10,5 \%$ - sugars $2,38-310 \%$ - acids tytruyutsya, $70,2-93,6$ $\mathrm{mg} / 100 \mathrm{~g}$ - ascorbic acid. In the accumulation of nutrients in the fruits of dogwood features affect both the variety and growing conditions year. For optimum ratio between the amount of rainfall and the active growing season temperatures in the fruits of dogwood accumulated more dry matter, sugars and acids, volumetric, and the high average temperature - less than ascorbic acid. Influence of weather rain winterspring period, including the amount of precipitation on the content of dry soluble substances, sugars and acids in fruit volumetric dogwood $(r=-0,94 \pm 0,00 \ldots r=0,52 \pm 0,05)$.

\section{References}

1. Klimenko S. Dogwood on the Ukraine / S. Klimenko. - K. Naukova dumka, 1980. - $174 \mathrm{p}$.

2. Klimenko S. // Actual problems botany in Armenia. Mater. Intl. Conf. Nov. 6-9. , 2008, Yerevan. Yerevan: In-t Botan. Munro, 2008. - P. 373-378.

3. Klymenko S. Drenjina (Cornus mas L.) socijalni, economski aspekti korišćenja, rezultati selekcije, obradivači. Zbornyk Radovis / S. Klimenko // Chetvrty Forum at orhanskoj proyzvod 4-25. September 2010 hours). - Selencha: Centar for orhansku proyzvodœu, 2010. P. 33-35.

4. Fan C. Phylogenetic relationships within Cornus (Cornaceae) based on $26 \mathrm{~S}$ rDNA quences / C. Fan, Q. - Y. Xiang // American Journal of Botany, 2001.88 (6), P. 1131-1138.

5. Brindza P. Slovakian Cornelian cherry (Cornus mas L.) rotential for cultivation / P. Brindza, D. Toth, S. Klimenko, O. Grigorieva // Acta Hort. - 760.-2007. - P. 433-437.

6. Tural S. Physico-chemical and antioxidant properties of cornelian cherry fruits (Cornus mas L.) grown in Turkey / S. Tural, I. Koca // Sci. Hortic. - 2008. - 116. - P. 362-366.

7. Dudukal G. Dogwood / G. Dudukalo, Y. Rudenko. - Chisinau: Shtyyntsa, 1984. - 94 p.

8. Dudukal G. Dogwood / G. Dudukalo, Y. Rudenko. — M:"Agropromizdat." - 1990. - 48 p.

9. Leontyak G. Dogwood - plants / G. Leontyak // gardening, viticulture and Winemaking Moldavyy. 1976. - № 3. - P. 56-57.

10. Leontyak G. Dogwood - plants / G. Leontyak. - Chisinau: Shtyyntsa, 1984. - 158 p.

11. The method of assessing the quality of fruits and berries / K .: IP. - 2008. - 80 p.

12. Dospechov $B$. Technique of field experiences (the basics of statistical processing of the results of the study)/B. Dospechov. - M.: Kolos, 1985. -416 p.

13. Leopold A. Growth and development of plants / A. Leopold. - M .: Mir, 1982. - $494 \mathrm{p}$.

14. Polevoy V. Physiology of plants / V. Polevoy. M .: Higher School, 1989. - 536 p. 